\title{
ローカルな公共交通のオペレーションにおける多国籍事業の背景*
}

\section{Background of Multinational Businesses for Local Public Transport Operations *}

\author{
柴山 多佳児**・家田 仁***
}

By Takeru SHIBAYAMA** • Hitoshi IEDA***

\section{1. はじめに}

複数の国で都市や地域の公共交通を運営する事業者 が、欧米を中心としながら世界各国で公共交通事業を展 開していることについては、筆者らによるこれまでの一 連の研究 1), 2)において指摘した。これまでの研究では、 こうした企業を「ローカル公共交通のグローバル・オぺ レータ」と呼び、フランスの Veolia Transport、Keolis、 Transdev ならびにイギリスの Arriva、National Express, Stagecoach, First Group、シンガポールの ComfortDelgro が主要なグローバル・オペレータとして挙げられること と、その事業展開先を整理した。中でも Veolia Transport, Arriva, Transdev, Keolis の主要 4 社は、展開先の国の数の 観点からは、特に顕著なグローバル・オペレータである ことも指摘した（表 1）。また、これらは、「自治体相 手・低リスク・低収益」ビジネスモデルで事業を行って いることを示した。さらに、フランス系のグローバル・ オペレータは、何らかの政府系機関の出資を、多かれ少 なかれ受けていることも示した（表2）注1）。

実際に、これら企業の利益率は低い。主要 4 社のう ち、上場企業である Arriva, Veolia Transport の 2 社と、 非上場ながら決算を公開している Keolis について、決 算報告書 3) 6) から入手可能な直近 3 年の利益率を算出 すると表 3 の通りとなる。Arriva こそ6〜7\%台の営業利 益をあげているが、Veolia Transport および Keolis 両社 の営業利益率は 2.52\%～4.34\%と小さいものである。

以上のことから「自治体相手・低リスク・低収益」 というだけで、各社が積極的に国際展開を進める動機に なるとは考えにくい。むしろ、何らか別のモチベーショ ンがあるからこそ、低収益であるにもかかわらず本拠国 外展開を積極的に進めるのだと考える方が自然であろう。

各社の本拠地の国外での事業の動機を探るためには、 (a) 経営層などに直接ヒアリングを実施し、その内部の 動機を明らかにすることと、(b) 各社ごとの展開方法の

*キーワード : 公共交通計画、公共交通運用

**学生員 東京大学大学院工学系研究科社会基盤学専攻 修士課程、

113-8656 東京都文京区本郷 7-3-1

Tel: 03-5841-6118, E-Mail: shibayama@trip.t.u-tokyo.ac.jp

***フェロー会員 工博 東京大学大学院工学系研究科社会基盤学専攻 教授
差異や出自・経営を分析することで、その特徵や背景を 整理すること、の両方が必要であると考えられる。

各社の決算報告書 ${ }^{3)}$ - 11)やウェブサイトからは、企業 としての規模や売り上げ、利益を成長させる方法として、 本拠国の外への展開を進めていく姿勢が明確に読み取れ る。また、企業自身の背景としては、事業を各国に分散 させることでリスク分散を図るなどの意図があることが 一般論として容易に想像される。したがって、あらかじ め(b)により背景などを明らかにした上で(a)を実施する ことで、一般的に想像しうる以上の、本拠国外展開の動

表 1 MOLTS と本拠、展開先 ${ }^{3)-11)}$

\begin{tabular}{|c|c|c|}
\hline MOLTS & 本拠地 & 展開先の国数 \\
\hline Veolia Transport & フランス & 30 \\
\hline Arriva & イギリス & 10 \\
\hline Transdev & フランス & 9 \\
\hline Keolis & フランス & 8 \\
\hline Comfort-DelGro & シンガポール & $5 *$ \\
\hline FirstGroup & イギリス & 4 \\
\hline National Express & イギリス & $2 * *$ \\
\hline Stagecoach & イギリス & $2 * * *$ \\
\hline
\end{tabular}

表 2 各社の主要株主

\begin{tabular}{|c|c|c|}
\hline 事業者グループ & 主な株主 & 保有率 \\
\hline \multirow{5}{*}{$\begin{array}{l}\text { Veolia } \\
\text { Environnement } \\
\text { (Veolia } \\
\text { Transport) }\end{array}$} & $\begin{array}{l}\text { Capital Research \& Management } \\
\text { Company } \\
\text { (金融ファンド) }\end{array}$ & $12 \%$ \\
\hline & $\begin{array}{l}\text { Caisse des Dépôts } \\
\text { (フランス政策投資銀行) }\end{array}$ & $10 \%$ \\
\hline & $\begin{array}{l}\text { Natixis Asset Management } \\
\text { (金融ファンド) }\end{array}$ & $7 \%$ \\
\hline & Groupama （金融グループ） & $6 \%$ \\
\hline & EDF （フランス電力） & $4 \%$ \\
\hline \multirow[t]{2}{*}{ Keolis } & $\begin{array}{l}\text { Axa Private Equity and Caisse des } \\
\text { Dépôts et placememt di Quebec } \\
(\text { (金融グループのジョイントベ } \\
\text { ンチャー) }\end{array}$ & $52 \%$ \\
\hline & SNCF （フランス国鉄） & $47 \%$ \\
\hline \multirow[t]{2}{*}{ Transdev } & $\begin{array}{l}\text { Caisse des Dépôts } \\
\text { (フランス政策投資銀行) }\end{array}$ & $68 \%$ \\
\hline & RATP （パリ交通公団） & $25 \%$ \\
\hline
\end{tabular}

以上 $2 つ$ 表 : 各社の年次報告書等より筆者作成 ※数值は2008 年末現在のものにアップデートした。 
表 3 各社の近年の売上と利益および利益率

\begin{tabular}{|l|l||c|c|c|}
\hline \multirow{3}{*}{$\begin{array}{l}\text { Veolia } \\
\text { Transport }\end{array}$} & 年 & 2002 & 2003 & 2004 \\
\cline { 2 - 5 } & 売上 & $€ 3.427$ & $€ 3.678$ & $€ 3.618$ \\
\cline { 2 - 5 } & 営業利益 (EBIT) & $€ 116$ & $€ 93$ & $€ 103$ \\
\cline { 2 - 5 } & 営業利益率 & $3.37 \%$ & $2.52 \%$ & $2.85 \%$ \\
\hline \multirow{4}{*}{ Keolis } & 年 & 2005 & 2006 & 2007 \\
\cline { 2 - 5 } & 売上 & $€ 2,419$ & $€ 2,664$ & $€ 2,883$ \\
\cline { 2 - 5 } & 営業利益 (EBIT) & $€ 67$ & $€ 89$ & $€ 125$ \\
\cline { 2 - 5 } & 営業利益率 & $2.77 \%$ & $3.34 \%$ & $4.34 \%$ \\
\hline \multirow{3}{*}{ Arriva } & 年 & 2005 & 2006 & 2007 \\
\cline { 2 - 5 } & 売上 & $£ 1,571$ & $£ 1,729$ & $£ 2,001$ \\
\cline { 2 - 5 } & 営業利益 (EBIT) & $£ 111$ & $£ 120$ & $£ 128$ \\
\cline { 2 - 5 } & 営業利益率 & $7.08 \%$ & $6.91 \%$ & $6.40 \%$ \\
\hline
\end{tabular}

各社年次報告書より筆者作成

機の核心に迫ることができると考えられる。

そこで、本稿では、文献とインタビュー調査に基づ き、上記(b)に該当する、各社ごとの展開方法の差異や、 経営層などの分析によって、特徽や背景の整理を行うこ とを目的した。そのために、はじめに(1)各社の展開スト ラテジーを整理・類型化を行った（第 2 章）。この過程 で、フランスの各社が特に路線の新規建設を絡めた展開 を得意とすることが判明しており、その背景を探るため に、(2)各社と本拠国政府や産業界との関連を、出資者や 役員構成などから検討し (第3 章) 、さらに(3)車両採択 に着目して、路線の新規建設と車両採択の関係を検討し た上で、さらに新規建設箇所における車両採択の実態を 調查した（第4 章）。また(4)第 2 章で得たフランスの各 社が新規建設を絡めた展開を得意とするとの知見と、第 3〜4 章で得た知見をもとに、それらの背景を英仏独の 比較を通して整理した (第5 章)。最後に(5)わが国の公 共交通オペレータへの示唆を整理した（第6 章）。

なお、本稿では、従来「グローバル・オペレータ」 と呼んでいた各社を、より実態を正確に表してい る "Multinational Operators for Local Transport Service" (MOLTS) と呼ぶ。

\section{MOLTS の展開ストラテジー}

\section{（1）モードごとの展開の特徵}

MOLTS 各社は、どのようなストラテジーのもとに事 業展開をしているのだろうか。筆者らの以前の研究では、 展開の様子を概観し、その本拠や事業の中心がヨーロッ パにあり、それ以外での主な展開先は北米やオセアニア であり、近年は中東やアジアでも展開が開始されている ことを示した。しかし、この「展開地域」という観点か らは、「なぜ展開するのか」という結論を導くには至ら なかった。

そこで、MOLTS 各社が、どの国にどのモードで展開 しているのかを各社の年次報告書やウェブサイト、さら に一部は役員などへのインタビューによってデータを補 充して整理した上で、参入している会社数の多いヨーロ ッパでの展開状況に着目して、整理し、表 4 にまとめた。

トラムでは、MOLTS はイギリス、フランスやスペイ ンに多いことがわかる。ドイツのように、トラムが運行 されている都市が多いからといって、必ずしも MOLTS の展開が進んでいるとは言えない。鉄道においては、イ ギリス、オランダ、ドイツといった国や北欧にその展開 が集中していることがわかる。しかし、バスにおいては、 都市部、都市間・地方部とも、イギリスやオランダが多 いことは確かだが、トラムや鉄道の場合のような一定の 傾向を見出しにくい。

トラムや鉄道事業には、そのための軌道などのインフ ラが必要である。以前の研究で指摘したように、 MOLTS 自身はインフラ整備・所有を担うことは基本的 になく、受け入れ先（MOLTS の展開先）の役割となる。 したがって、MOLTS の展開先（受け入れ先）と、そう でない国・地域の政策や歴史的展開の差異が、事業展開 に大きく影響をしていると考えられる。バスは、トラム や鉄道と比べて簡素な設備で事業ができることから、受 け入れ側の役割がかなり限定的であることも考え合わせ ると、政策的な影響よりは、企業としての展開戦略の方

表 4 各国のモード・国ごとの展開している MOLTS の数

\begin{tabular}{lc}
\hline \hline \multicolumn{2}{c}{ Tram/Light Rail } \\
\hline \hline \multicolumn{1}{c}{ Country } & \# of MOLTS \\
\hline \hline United Kingdom & 4 \\
France & 3 \\
Spain & 2 \\
Sweden & 1 \\
Norway & 1 \\
Ireland & 1 \\
Germany & 1 \\
Portugal & 1 \\
\hline \hline
\end{tabular}

\begin{tabular}{lc}
\hline \hline \multicolumn{2}{c}{ Regional Rail } \\
\hline \hline \multicolumn{1}{c}{ Country } & \# of MOLTS \\
\hline \hline United Kingdom & 5 \\
The Netehrlands & 4 \\
Germany & 3 \\
Sweden & 2 \\
Poland & 1 \\
France & 1 \\
Demnark & 1 \\
\hline \hline
\end{tabular}

※対象としているのは、 Veolia Transport, Arriva, Transdev, Keolis, Stagecoache, Nationa Express, First Group, ComfortDelGroのヨーロッパにおける事業のみである。

※各社の公共交通の「オベレーション」事業を対象とし、調査事務所等の設置は数えていない。 ※”Urban Bus"|都市内のバスのオベレーション老"Interurban/Regional Bus”は、都市間をつ なぎがら地方部のバスをオペレートしている形態を指可。

※各社の年次報告書から筆者作成。

\begin{tabular}{lc}
\hline \hline \multicolumn{2}{c}{ Urban Bus } \\
\hline \hline \multicolumn{1}{c}{ Country } & \# of MOLIS \\
\hline \hline United Kingdom & 7 \\
The Netherlands & 3 \\
Sweden & 3 \\
France & 3 \\
Germany & 1 \\
Finnland & 1 \\
Belgium & 1 \\
\hline \hline
\end{tabular}

\begin{tabular}{lc}
\hline \hline \multicolumn{2}{c}{ Interurban/Regional BuS } \\
\hline \hline \multicolumn{1}{c}{ Country } & \# of MOLIS \\
\hline \hline United Kingdom & 6 \\
The Netherlands & 4 \\
Germany & 3 \\
France & 3 \\
Spain & 2 \\
Portugal & 2 \\
Italy & 2 \\
Czech Republic & 2 \\
Sweden & 1 \\
Slovenia & 1 \\
Slovakia & 1 \\
Serbia & 1 \\
Poland & 1 \\
Norway & 1 \\
Ireland & 1 \\
Finnland & 1 \\
Denmark & 1 \\
\hline \hline
\end{tabular}



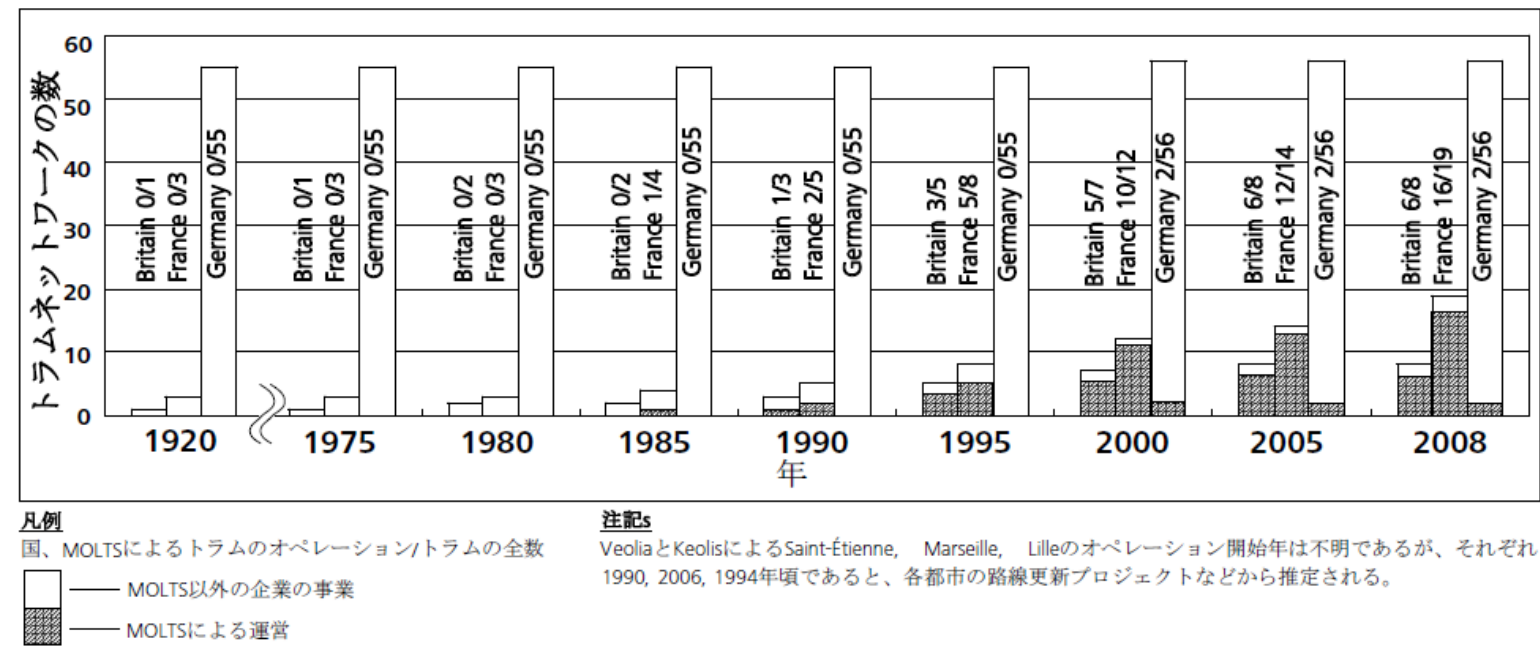

注記s

VeoliaとKeolisによるSaint-Étienne， Marseille，Lilleのオペレーション開始年は不明であるが、それぞれ 1990, 2006, 1994年頃であると、各都市の路線更新プロジェクトなどから推定される。

図 1 : 英仏独の現存するトラムのネットワークの数と MOLTS の事業の年次変化（筆者作成）

がより大きく影響していると考えられる。

そこで、トラムについては、MOLTS の展開が多い英 仏と、展開が少ないドイツについて、開業年とオペレー タ着目して全てのトラムネットワークを整理することで、 MOLTS の展開の特徵を見出した。鉄道は、鉄道市場の 状況をインデックス化した Railway Liberalization Index ${ }^{12)}$ との関連から、その特徵を整理した。さらに、バスは、 インタビュー等から、特に企業としての展開戦略を整理 することで、その特徽を整理した。

\section{（2）トラム事業の展開の特徴}

MOLTS の展開は、先述の通り、英仏への集中が顕著 である。そこで、比較のため、トラムのネットワークは 多いものの MOLTS の展開が少ないドイツを加えた 3 ヶ 国の、全てのトラムのネットワークについて、開業年と オペレータを、各種文献 ${ }^{13)}$ - ${ }^{15}$ 加ら整理した。それをも とにして、現時点（2008 年 9 月時点）で開業されてい るトラムネットワークの数を整理したのが、図 1 である。

図 1 からは、次の 4 点が読み取れる。(1)ドイツの現 存するトラムの大半は、1920 年までには営業を開始し ている一方で、英国、フランスに 1920 年時点で存在し ていたトラムは、それぞれ 1 都市、3 都市しか現在残つ ていない。その一方で(2)1980 年頃を境にして、英国、 フランスでは新たなトラムの建設が急増している。さら に、(31990 年ころより、英仏では MOLTS の事業が急 に桩大しているが、ドイツではその動きは目立たない。 そして、(4)2008 年時点では、英仏のトラムの大半は MOLTS により運営されている一方、ドイツのトラムの 大半はMOLTS 以外のオペレータにより運営されている。

フランスとイギリスの 1980 年代以降のトラムの増加 は、いわゆる「トラムの復活」の動きに重なる。この 「トラム復活」が、英仏での MOLTS のトラム事業拡大 の鍵となっていることがうかがえる。実際、フランスに
現存する 1980 年以降に開業した 16 のトラムのうち、パ リ、ミュルハウス、クレモンフェランを除く 13 のネッ トワークが MOLTS により運営されている。また、イギ リスでは、1980 年以降 5 つの都市でトラムが新たに開 業しているが、すべて MOLTS による運営である注2)。

こうした、新規に建設されるネットワークの運営に よる事業展開は、「新設事業型」と呼ぶことができる。 MOLTS の全 30 箇所のトラム事業のうち、「新設事業 型」のトラム事業展開に該当するものは、Veolia Transport は、ドイツ東部の都市などを除く 7 都市、 Keolis はフランスのリールを除く 2 都市、Transdev はオ 一ストラリアのメルボルンを除く 9 都市、Stagecoach, National Express, First Group は運営する英国内の合計全 5 都市の、合計 23 都市が該当するが、該当しないものは 各社を合計しても 7都市のみである。

したがって、MOLTS のトラム事業は、1980 年以降に 新たに建設・導入されたトラムのオペレーションを行う

「新設事業型」の形態が最も顕著な特徴であるといえる。

\section{（3）鉄道事業の展開の特徴}

MOLTS の鉄道事業の展開は、先述したように、国ご との鉄道施策の差異が影響していると考えられる。そこ で、国鉄ネットワークの民間への解放に着目し、IBM Global Business Service がまとめた、Railway Liberalization Index ${ }^{12)}$ と、MOLTS の展開の現状を比較した。表 5 に、

この Railway Liberalization Index を構成する、LIB-Index （制度や情報量など、参入するポテンシャルを 1000 点 満点で数值化）と COM-Index（旧国鉄以外のオペレー タの参入など、実際の競争状況を 1000 点満点で数值 化）を示し、さらにMOLTS 展開の有無を整理した。な お、Railway Liberalization Index の対象が 29 ケ国と多い ことから、LIB-Index の上位 10 ヶ国とフランスのみを示 した。 
表 5 : Railway Liberalization Index と MOLTS の事業

\begin{tabular}{|c|c|c|c|c|}
\hline $\begin{array}{c}\text { 順位 } \\
\text { (LIB-Index) }\end{array}$ & 国 & $\begin{array}{l}\text { LIB- } \\
\text { Index* }\end{array}$ & $\begin{array}{l}\text { COM- } \\
\text { Index* }\end{array}$ & $\begin{array}{l}\text { MOLTS } \sigma \\
\text { 参入(鉄道) }\end{array}$ \\
\hline 1 & ドイツ & 809 & 555 & あり \\
\hline 2 & 英国 & 798 & 793 & あり \\
\hline 3 & デンマーク & 757 & 498 & あり \\
\hline 4 & スウェーデン & 742 & 633 & あり \\
\hline 5 & オランダ & 732 & 509 & あり \\
\hline 6 & オーストリア & 727 & 349 & なし \\
\hline 7 & ポーランド & 692 & 490 & あり \\
\hline 8 & チェコ & 679 & 279 & あり \\
\hline 9 & エストニア & 667 & 704 & なし \\
\hline 10 & スイス & 662 & 459 & なし \\
\hline 27 & フランス & 431 & 178 & あり*** \\
\hline
\end{tabular}

出典 : IBM Global Business Services 2007 (Indices) および独自調査 (MOLTS 事業)

*LIB-Index は旅客輸送のみの值が提供されているのでその值を用いた が、COM-Index は旅客・貨物の混合值のみが提供されているので、そ の值を使用した。

**インデックスは 2007 年現在、MOLTS の事業は 2008 年現在。

***観光用鉄道の運営を SNCF が Veolia Transport に委託しているもの

LIB-Index の上位 10 力国の多くでは、表 5 の通り MOLTS による鉄道事業が行われている。11 位以下で MOLTS の鉄道事業が行われているのはフランス (LIBIndex で 27 位) のみであるが、これは地方部の一部の 観光向け鉄道の運営を SNCF が Veolia Transport に委託 しているものであり、例外的なものと考えられる。

以上からは、鉄道の自由化が進んだ国ほど、MOLTS の鉄道事業への参入が多い、ということが確認される。 かつその展開形態は、既存の国鉄サービスを、何らかの 制度的プラットフォームに基づいて置き換えるケースが

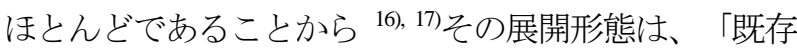
事業置換型」として整理できよう。たとえば、Veolia Transport はドイツではドイツ鉄道 DB 以外では最大の 鉄道事業者であり、バイエルン州やニーダーザクセン州 の地方鉄道の運営を行っているほか、2010 年より導入 されるブレーメンの S-Bahn（近郊電車）の運営も担う 予定となっている。これらは全て DB のネットワーク上 での事業であり、上下分離施策などによって解放された 市場に MOLTS が参入している姿がうかがえる。

\section{（4）バス事業の展開の特徴}

先述したとおり、バス事業による展開先には、表 4 の データのタからでは、顕著な傾向を見出すことが難しい。 会社の数は英蘭独仏などが多いが、 1 社の久展開してい る国も含めると非常に広い範囲で展開していることがわ かる。

しかし、Veolia Transport の子会社であり、スロベニ ア国内でバス事業を展開する、Veolia Transport Slovenia の代表取締役である Bo Karlsson 氏からは、「Veolia は 地元のバス会社を買収し、それを足がかりに事業を広げ ていくことが多い。スロベニアもこのケースに該当する。
また、ハンガリーなどには調査事務所を持っており、買 収先がないか調査している。」との証言を得ることがで きた。また、ヨーロッパの事例ではないが、中国に展開 している Veolia Transport China は、地元の半官半民のバ ス会社である Nanjing Zhongbei（南京中北）とのジョイ ント・ベンチャー（JV）を設立することによって、

Nanjing Zhongbei の事業を継承していく ${ }^{18)}$ 形態を取って いる。また、近年の大きな買収としては、米国の長距離 バスオペレータである Greyhound 社を買収した First Group の事例が挙げられる。

以上のような証言や事実などから、バスの展開は 「他社吸収型」とまとめられよう。買収、JV の設立な ぞ方法は様々であるが、既存の地元バス会社を自社の中 に吸収していくことによって、バス事業の展開を進めて いるのが MOLTS のバス事業展開である。

\section{（5）モード · 展開の特徵と企業ごとの差異 · 特徴}

これまでに挙げた事柄から、各社の主要なモードに おいてのヨーロッパでの展開戦略は、「新設事業型」

（トラム）、「既存事業置換型」（鉄道）、「他社吸収 型」（バス）という3つの形態に、おおむね就モードとの 一対一対応として、類型化される。では、全ての会社が 全ての形態での展開をしているのだろうか。

MOLTS 各社はすべて、本拠地とする国以外でバス事 業を展開している。鉄道事業も各社が行っており、 Veolia, Arriva, Keolis, Transdev, FirstGroup の 5 社が本拠国 外で展開を行っている。このことから「既存事業置換 型」と、「他社吸収型」の 2 形態はいわば「どの MOLTS でもできる」形態と言える。

しかし、トラムの事業を展開しているのは、Veolia Transport, Keolis, Transdev, First Group, Stagecoach, National Express の 6 社であり、さらに本拠地とする国の外でも トラム事業を展開しているのは、Veolia Transport（本拠 地のフランス以外で5 ヶ国) と Transdev（同 3 ヶ国）の みであり、他の各社は本拠とする国の中での事業にとど まっている。したがって、「新設事業型」かつ本拠国外 への展開は、フランスの 2 社にの久顕著であり、この 2 社は他の MOLTS とは異なる何らかの特質を持っている と考えられる。

筆者らの以前の研究 ${ }^{2)}$ でも指摘したとおり、新規建設 を伴う鉄道やトラム事業における、車両や設備の調達で の本拠国企業への利益還元や、MOLTS を通じた車両や インフラの規格統一による本拠国仕様のデファクト・ス タンダード化を狙うことも、本拠国政府や産業界の思惑 としてあり得る。いわば「産業コンプレックスの形成を 通じた、本拠国産業の覇権を狙う」思惑もあり得よう。

トラム、鉄道、バスを比較すると、鉄道やトラムが 線路や信号などインフラと技術を必要と寸るのに対して、 
バスは相対的に容易な技術のみで参入が可能である。ま た、先述のように、鉄道事業のインフラはオペレータの 管理下には原則としてないことから、オペレータの影響 力は車両のみに行使できうるのに対し、トラム事業は新 規建設が関連する事業が多く、インフラに対してもオぺ レータの独自性の発揮や影響力の行使が一定程度は可能 と考えられる。

次章では、この観点から、フランスの MOLTS、中で も Veolia Transport と Transdev に着目して、これらの本 拠地とするフランスの政府や産業界との関連を調査・整 理する。

\section{3. 本拠国政府・産業界とフランスのMOLTSの関係}

「はじめに」でも示したように、筆者らの以前の研究 で、フランスの MOLTS は、何かしらのフランスの政府 系機関からの出資を受けていることを明らかにした注 ${ }^{3)}$ 。

では、取締役メンバーはどのようになっているので あろうか。一例として Veolia Environnement の取締役を 調査すると、14人の取締役（2008 年現在）には、社外 取締役として、フランスの大手銀行 Société Générale 頭 取の Daniel Bouton 氏、同じく大手銀行である BNP Paribas 頭取の Baudouin Prot 氏、出資者でもある金融グ ループ Groupama の CEO である Jean Azema 氏、イタリ アのエネルギー企業エネル社 CEO の Paolo Scaroni 氏、 自動車メーカーのルノー会長の Louis Schweitzer 氏、ホ テル経営で知られる Accor グループ CEO を務めた JeanMarc Espalioux 氏などが名を連ねている。また、Veolia Transport 社の CEO である Cyrille du Peloux 氏は、もと もとフランス政府産業省出身であり、仏大手建設会社 Bouygues での職務経験も持つ7),19)-21)。

以上のように、Veolia Transport については、社外取締 役の顔ぶれなどからは、フランスの MOLTS と、政府や 産業界との非常に強いかがりがあることが推察される。 また、Transdevは、先に示したように、その出資者のほ ぼ全てが公共セクターであり、形態としては民間企業で ありながらも、実質的には政府系機関に近い位置にある ものと推測される。なお Keolis も、出資の約半分がフ ランス国鉄であるから、やはり公共セクター色が強い。

イギリスの MOLTS については、株主は公開されてい ないが、経営層を調査すると、以下の通りとなる。

Arriva の会長である Sir Richard Broadbent 氏は、 Securities Institute や Schroders PLC、Berkley をはじめと する金融・不動産企業の出身である。また、同社の最高 経営責任者である David Martin 氏は Arriva の前身となる British Bus 社の出身、財務担当取締役を勤める Steve Lonsdale 氏は、会計・コンサルタント企業である PriceWaterhouseCoopers 社の前身である Coopers \&
Lybrand 社の出身である。

National Express 社は、インフラマネジメント企業の Telent や、自動車部品メーカーの Kelsey Hayes などの出 身の John Devaney 氏（経営責任者）や、FirstGroup 出身 の Ray O’Toole 氏（運行部門担当取締役）、食品産業 (Northern Foods plc) や不動産業（Britannia Building Society）などに経歴を持つ Jez Maiden 氏（財務担当取締 役）、コンピュータ関連企業 ARM Holdings plc の Tim Score 氏（社外取締役）らが名を連ねている。

First Group の会長である Martin Gilbert 氏は、不動産会 社である Aberdeen Asset Management PLC の創立者であ る。また、同社の前身の GRT Bus Group 時代からの Sir Moir Lockhead 氏が副会長兼経営責任者を、Sidney Barrie 氏が営業担当取締役を務めるなど、前身となるバス会社 からの生え抜きの人材が多い。なお、2009 年より取締 役を務める Nicola Shaw 氏は、Office of Rail Regulation や London Transport など行政系でのキャリアを持つほか、 社外取締役にはロンドン地下鉄公社出身の人物などが含 まれるなど、公共セクター系の役員も多い。

Stagecoach 社は、会長である Brian Souter 氏は同社の 設立者であり、非常勤会長である Robert Speirs 氏は Royal Bank of Scotland (RBS) などに経歴を持つ。また、 財務担当取締役である Martin Griffiths 氏はVirgin Rail 共 同代表や Glasgow Income Trust plc の社外取締役を務め ている。

以上から、フランスの MOLTS が政府系機関や本拠と する国の基幹となる各種の産業に近い立場である推察さ れるのに対して、イギリスの MOLTS は金融業や不動産 業をはじめとする民間の産業と強いつながりを持つ立場 であることが示唆される。 MOLTS 各社の形態はいずれ も民間企業であるが、フランスの MOLTS がは公共セク タ一色を色濃く持つことは、特筆すべきことである。

\section{4. 路線新規建設と車両採択の関係}

\section{（1）「新設事業型」のトラム事業と他のトラム事業}

第 2 章で指摘したように、新規建設を含んだトラム 事業や鉄道事業では、MOLTS は車両やインフラの基本 的な規格の決定に影響力を行使できると考えられる。前 章で指摘した、フランスの MOLTS の事業と本拠国の政 府や産業には、強い関連性が見出せるはずである。

筆者らの以前の研究 ${ }^{2)}$ においては、フランスの企業で あり最大手の MOLTS である Veolia Transport 社につい ては、インフラの新規建設段階からオペレーションを行 つている箇所、すなわち「新設事業型」の形態でトラム 事業を行っている都市では、フランスに製造拠点を持っ メーカ一の車両が使われている傾向があることを簡単に 述べたが、その詳細は表 6 (次頁) の通りである。 
表 6 Veolia Transport のトラム事業地とその種別および 車両供給元（同社年次報告書等から筆者作成）

\begin{tabular}{|c|c|c|c|c|c|}
\hline $\begin{array}{l}\text { 種 } \\
\text { 別 }\end{array}$ & 都市 & 国 & 車両製造 & 開業 & $\begin{array}{l}\text { Veolia } \\
\text { 事業開始 }\end{array}$ \\
\hline \multirow{7}{*}{$\begin{array}{l}\text { 新 } \\
\text { 設 } \\
\text { 事 } \\
\text { 業 } \\
\text { 型 }\end{array}$} & バルセロナ & スペイン & アルストム & 2004 & 2004 \\
\hline & ボルドー & フランス & アルストム & 2003 & 2003 \\
\hline & ダブリン & アイルランド & アルストム & 2004 & 2004 \\
\hline & ナンシー & フランス & ボンバルディア & 2000 & 2000 \\
\hline & ルーアン & フランス & アルストム & 1994 & 1994 \\
\hline & ストックホルム & スウェーデン & ボンバルディア & 2000 & 2000 \\
\hline & シドニー & オーストラリア & ホホンバルディア & 1997 & 1997 \\
\hline \multirow{5}{*}{$\begin{array}{l}\text { 既 } \\
\text { 存 } \\
\text { 事 } \\
\text { 業 } \\
\text { 置 } \\
\text { 換 } \\
\text { 型 }\end{array}$} & $\begin{array}{c}\text { シェーナイヒャーニリュ } \\
\text { ーデスドルフ }\end{array}$ & ドイツ & $\begin{array}{l}\text { タトラ } \\
\text { デュワグ }\end{array}$ & 1910 & 2001 \\
\hline & ゲルリッツ & ドイツ & タトラ & 1881 & 2001 \\
\hline & ルシショーピン & スウェーデン & デュワグ & 1904 & 2004 \\
\hline & サンテテイエンヌ & フランス & アルストム & 1881 & $-* *$ \\
\hline & トロン八イム & ノルウェー & $\begin{array}{c}\text { リンケ=ホフマン } \\
\text { ブッシュ }\end{array}$ & $\begin{array}{c}1990 \\
\text { (再開) }\end{array}$ & 2004 \\
\hline
\end{tabular}

**筆者調查時点で入手不可能。

同社の 12 都市でのトラム事業（2007 年末現在）のう ち、7 都市が「新設事業型」である。残る 5 都市は「既 存事業置換型」である。本拠国フランスのほか、アイル ランド、スペインなどにも「新規事業型」の都市が見ら れる。「既存事業置換型」は、MOLTS の事業としては 例外的なものであるが（第2 章参照）、旧東ドイツや北 欧を中心にみられ、これらはいずれも地元の企業の買収 により経営権を獲得した都市である。

ここで車両メーカーに着目すると、「新設事業型」 の箅所では、 7 都市中 4 都市でアルストム社が、3 都市 でボンバルディア社（合併前のアドトランツを含む）の トラム車両が採用されていることがわかる。一方、「既 存事業置換型」の箇所では、タトラ社（チェコの車両メ 一カー) 、デュワグ社（現在はドイツのシーメンスに合 併）などによる製造が多い。以上のように Veolia Transport の「新設事業型」の箇所におけるトラム車両
の採択にはメーカーの偏りがみられる。

\section{（2）「新設事業型」には必ずAlstom か Bombardier}

さらに、Veolia, Keolis, Transdev 各社のトラムの「新 設事業型」の都市の車両と、軌間や電圧を表 7 にまとめ た。

この結果から、MOLTS のすべてのトラムの「新設事 業型」の箇所で、アルストム社かボンバルディア社の車 両が導入されていることがわかる。さらに、ほぼ全てに 共通して、1,435mm の標準軌と直流 750V の規格が採用 されている。また、その展開先は、スペイン、イタリア、 ポルトガル、イギリス、アイルランドにまたがっている。

以上から、フランス系 MOLTS のトラムの「新設事業 型」の都市と、導入される車両のメーカーやインフラの 規格には、アルストムとボンバルディアというフランス 系製品と強い関連性が見出せる。MOLTS がフランス系 メーカーの車両採択になんらか関与することにより、本 拠国のトラム車両産業に利益をもたらしてきたことが推 察される。

一方では、ドイツなどの上記以外のヨーロッパ各国 ではMOLTS のトラムの「新設事業型」の都市が見られ ないことも指摘される。この点については、ドイツや東 欧の諸都市では、従来からの路面電車インフラを廃止せ ず、それを改良して現在も使用しているケースが多いこ とを考えると、新規建設が不要であることから、自然な 帰結と見ることができる。

\section{（3）トラム「復活」と MOLTS 展開の相互作用の可能性}

ところで、これらの MOLTS のトラムの「新設事業 型」の事業には、早い段階でトラムを「復活」させたフ ランスのナントとグルノーブル、都市計画との融合で知

表 7 フランスの MOLTS の新規事業地における車両とインフラの規格（各社資料等から筆者作成） 22) 23) 注4)

\begin{tabular}{|c|c|c|c|c|c|c|c|}
\hline 事業者 & 都市 & 国 & 開業 & 軌間 & 電圧 & 車両メーカー & 注記 • 特記事項 \\
\hline \multirow{7}{*}{$\begin{array}{l}\text { Veolia } \\
\text { Transport }\end{array}$} & バルセロナ & スペイン & 2004 & $1,435 \mathrm{~mm}$ & $750 \mathrm{~V}$ DC & アルストム & 事業会社にアルストムも出資 \\
\hline & ボルドー & フランス & 2003 & $1,435 \mathrm{~mm}$ & $750 V$ DC & アルストム & APS（地表集電） \\
\hline & ダブリン & アイルランド & 2004 & $1,435 \mathrm{~mm}$ & $750 \mathrm{~V}$ DC & アルストム & \\
\hline & ナンシー & フランス & 2000 & N/A & $600 \mathrm{~V}$ DC & ボンバルディア & TVR（ゴムタイヤ式） \\
\hline & ルーアン & フランス & 1994 & $1,435 \mathrm{~mm}$ & $750 \mathrm{~V}$ DC & アルストム & \\
\hline & ストックホルム & スウェーデン & 2000 & $1,435 \mathrm{~mm}$ & $-*$ & ボンバルディア & *筆者調查時点で入手不能 \\
\hline & シドニー & オーストラリア & 1997 & $1,435 \mathrm{~mm}$ & $750 \mathrm{~V}$ DC & ボンバルディア & アドトランツ時代 \\
\hline \multirow{2}{*}{ Keolis } & カーン & フランス & 2002 & N/A & $750 \mathrm{~V} D C$ & ボンバルディア & TVR（ゴムタイヤ式） \\
\hline & リヨン & フランス & 2001 & $1,435 \mathrm{~mm}$ & $750 \mathrm{~V}$ DC & アルストム & \\
\hline \multirow{9}{*}{ Transdev } & テネリフェ & スペイン & 2007 & $1,435 \mathrm{~mm}$ & $750 \mathrm{~V} \mathrm{DC}$ & アルストム & カナリア諸島の都市 \\
\hline & ノッティンガム & イギリス & 2004 & $1,435 \mathrm{~mm}$ & $750 \mathrm{~V}$ DC & ボンバルディア & \\
\hline & ミュルハウス & フランス & 2006 & $1,435 \mathrm{~mm}$ & $750 \mathrm{~V}$ DC & アルストム & \\
\hline & ストラスブール & フランス & 1994 & $1,435 \mathrm{~mm}$ & $750 \mathrm{~V}$ DC & ボンバルディア、アルストム & ボンバルディア分はアトトトラン゙时代を老含む \\
\hline & グルノーブル & フランス & 1987 & $1,435 \mathrm{~mm}$ & $750 \mathrm{~V}$ DC & アルストム & \\
\hline & モンペリエ & フランス & 2000 & $1,435 \mathrm{~mm}$ & $750 \mathrm{~V}$ DC & アルストム & \\
\hline & オルレアン & フランス & 2000 & $1,435 \mathrm{~mm}$ & $750 \mathrm{~V}$ DC & アルストム & 一部路線は APS \\
\hline & ナント & フランス & 1985 & $1,435 \mathrm{~mm}$ & $750 \mathrm{~V}$ DC & アルストム、ボンバルディア & \\
\hline & ポルト & ポルトガル & 2003 & $1,435 \mathrm{~mm}$ & $750 \mathrm{~V}$ DC & ボンバルディア & 注 5) \\
\hline
\end{tabular}

*筆者調査時点で入手不可能。 
られるストラスブール、ゴムタイヤ式トラムの採用で知 られるナンシーとカーン、地表集電方式で知られるボル ドーといった、フランスの近年の「トラム復活」を牽引 してきた諸都市 ${ }^{24)}$ がすべて含まれている。であるなら ば、これら一連の「トラム復活」の流れの中で、 MOLTS がオペレーションの開始において一定の寄与を した可能性はないだろうか。また、これらフランス系の 技術を各所に導入することにより、トラム技術のデファ クト・スタンダード化が推し進められた、という可能性 はないだろうか。

Transdev の事業地であり、先陣を切って 1985 年にト ラムを復活させたナント都市圏自治体連合交通部部長で あり、元 Veolia Transport の研究員でもある Eric Chevalier 氏からは「SEMITAN（ナント都市圏の公共交 通オペレータ）へは、公共交通、特にトラムの運営のス ペシャリストとして Transdev が参画した」との証言を 得られた。また SEMITAN のマーケティング部長であ る Christine Lassalle 氏によれば「ナントはTransdevから 得たものよりは（その後の他の都市の展開のために）同 社に供したものの方が多い」と証言を得られた。

こうしたことから、MOLTS の展開が一つの強力な後 押しとなって、フランスをはじめとする各所でトラム

「復活」が容易になったことが推察される。特に、新た にトラムを導入する場合に、メンテナンスや信号管理の ノウハウにかかわる人材の確保といった、運営上の専門 的側面を担う企業として、MOLTS がかかわることでそ のハードルが下げられていたと考えられる。

さらに、MOLTS の「新設事業型」の拡張が、他都市 からのノウハウの移入などによりトラム導入のハードル を下げ、それがトラムの (再) 導入を決める都市を増や し、MOLTS の「新設事業型」の機会が増加する、とい った、何らかの相乗効果があった可能性も考えられる。 こうした点に関しては、今後の研究の課題である。

\section{5. フランスの MOLTS が本拠国外で「新設事業型」展 開ができる背景}

「新設事業型」かつ本拠国外への展開は、フランス の 2 社（Veolia, Transdev）にのみ顕著であることは、第 2 章で指摘した。また、第 3 章や第 4 章からは、フラン スの MOLTS が公共セクター色が強いこと、フランスの MOLTS と同国のトラム車両産業に強い関連が見られる ことを指摘した。

であるならば、フランスには、こうした MOLTS の 展開が可能になる何らかの背景があるはずである。本章 では、フランスとともに MOLTS を数多く抱えるイギリ スと、「運輸連合」(Verkehrsverbund) 25)などに代表され る公共交通分野での蓄積を多く持っているドイツの比較
によって、その背景を探る。

これまでの調査をまとめると、(1)MOLTS が存在する ことが必要で、(2)トラム・鉄道の車両の産業がが存在し、 本拠国で(3)「新設事業型」の展開ができる可能性が必要 であると考えられる。この 3 点に注目して比較する。

\section{（1）MOLTS の存在}

本稿の冒頭で紹介したように、MOLTS と呼ぶべき企 業は 8 社中 7 社がフランスまたはイギリスを本拠とする。 ドイツはMOLTS と呼ぶべき企業を輩出していない。

イギリスでは、1980 年代の国営バス会社民営化の後、 いったん小さな会社が数多く生まれたが、その後合併に よる集約が進み、「5 大グループ」などと呼ばれる企業 群 - National Express, First Group, Arriva, Stagecoach, GoAhead - を形成した。これらは後に鉄道が民営化さ れた際には鉄道のオペレーションにも進出し、また、 MOLTS として各国にも展開を行っている 26),27)。

フランスでは、1970 年代後半からの合併の繰り返し により、Veolia Tranpsort, Keolis が生まれている。Veolia の交通部門は CGEA と呼ばれていた企業を母体として 買収を繰り返して成長した。Keolis は舟運会社に起源を 持つ VIA-GTI 社と、フランス国鉄 SNCF のバス事業部 門が合併したものである。また Transdev は比較的「国 策」色が強い政策投資銀行系の企業であることは、前述 の通りである。

このように、イギリスとフランスでは、主に合併の繰 り返しによって大きなオペレータが形成され、その多く

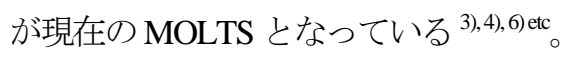

その一方で、ドイツでは、各地の公共交通は都市ごと の「Stadtwerke」と呼ばれる公営企業が担う形態が伝統 的に続いてきた。この企業は、電力、集中暖房、ごみの 回収、公共交通事業など、都市公共サービスを独占的に 担う 29)etc。また、国鉄網も、1994 年の民営化後も、ドイ ツ鉄道 DB の寡占に近い状態が続いており、近距離旅客 輸送では現在でも 8 割以上のシェアを占めている 17), 30)32)。こうした状況から、少なくとも現時点までは、ド イツでは合併が進まず、小さなオペレータが数多くある 状況が続いていると考えられる。

MOLTS として展開するには、ある程度の資金力、人 材、技術といった面での企業としての「体力」が必要が あると考えられる。中小の企業が MOLTS として世界に 展開していくのは難しいであろう。実際、MOLTS はど れも現時点で数万人規模の従業員をもつ企業である ${ }^{3-11)}$ こうしたことから、1970 年代ないし 1980 年代以降に進 んだ合併による大きなオペレータの成立が、MOLTS を 形成しうる一要因となっていると考えられる。 


\section{（2）鉄道車両産業の「ビッグ3」とフランス}

ここでは、世界の鉄道車両産業とフランスの鉄道車両 産業を、トラムに重点を置きながら概観・整理する。

アルストム社の資料 33)によれば、世界の鉄道車両シ エア（2001 年から 2006 年の受注数）は、表 8 の通りで ある。先述の MOLTS の新規事業で使われるメーカーで あるボンバルディア、アルストムは世界の鉄道車両シェ アの 21\%（1 位）、19\%（2 位）をそれぞれ占めている。 また、ボンバルディア社資料 ${ }^{14)}$ によれば、両社は 1987 年以来生産・販売で提携を結んでいる注 6)。また、ドイ ツのジーメンス社は、MOLTS の新規事業では導入され ていないが、第3位の市場シェアを持つ。この 3 社のシ エアを合計すると $56 \%$ になり、鉄道車両製造の「ビッ グ $3 」$ と呼ぶべき存在である。

ボンバルディア社はわが国ではカナダの航空機メー カーとして知られるが、ベルリンを本拠とする鉄道車両 部門を持つ。1971 年にオーストリアの Lohnerwerke を 買収したのを皮切りに、1989 年にフランスの大手鉄道 車両メーカーAND-Industrie、2001 年にドイツのダイム ラー・クライスラーの鉄道車両部門であった AdTranz 社を買収し、ヨーロッパでの事業展開を進めている。フ ランス北部のクレスパンやオーストリアのウィーン、ド イツのアーヘン近郊などと、北米各所に鉄道車両製造拠 点を持つ。トラムは「Flexity」として展開し、ストラス ブール型のトラム車両「Eurotram」などを製造するほか、 TVR（Transport sur Voie Réservée）として知られるゴム タイヤ式・レール1本のトラムを開発したほか、近年に はPRIMOVE として架線なしトラムを発表した ${ }^{34,35) 。 ~}$

一方、アルストム社は発電機と鉄道車両を手がける フランスの重工メーカーであり、西部のラ・ロシェルに 鉄道車両製造拠点を持つほか、1998 年にドイツ有数の 鉄道車両メーカーLinke-Hofmann-Busch 社を買収し、ド イツにも拠点を持つ。トラム車両は「Citadis」として展 開しており、その一部として、地表集電方式の APS

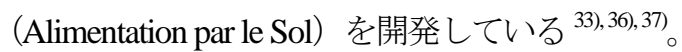

第 3 位のジーメンス社はドイツを代表する総合電機 メーカーである。トラムの車両では「Combino」として 展開している。ドイツを中心に鉄道製造拠点を持つ ${ }^{38)}$ 。

以上のことから、フランスとドイツにはトラム・鉄道 車両製造の「ビッグ $3 」$ が重要な製造拠点を構えており、 強力な鉄道車両製造産業が存在することがわかる。

これに対してイギリスは、こうした強力な鉄道車両産業 がない。現在の世界の鉄道車両製造産業を牽引する企業 はイギリスにはない、と言っても過言ではないだろう。

\section{（3）自国内で「新設事業型」の展開ができる可能性}

2 - (2) 節で述べた通り、トラムの分野では、イギリス とフランスはその「復活」が 1980 年代以降続いている。
表 8 世界の鉄道車両のメーカー別シェア

\begin{tabular}{|c|c|c|}
\hline 車両メーカー & 本拠地の国 & 市場シェア \\
\hline Bombardier & カナダトドツ & $21 \%$ \\
\hline Alstom & フランス & $19 \%$ \\
\hline Siemens & ドイツ & $16 \%$ \\
\hline General Electric & アメリカ & $8 \%$ \\
\hline Ansaldo & イタリア & $5 \%$ \\
\hline Rotem & 韓国 & $2 \%$ \\
\hline EMD & アメリカ & $3 \%$ \\
\hline CAF & スペイン & $1.5 \%$ \\
\hline Stadler & スイス & $1.5 \%$ \\
\hline 日本企業群 & 日本 & $9 \%$ \\
\hline 中国企業群 & 中国 & $7 \%$ \\
\hline その他 & N/A & $7 \%$ \\
\hline
\end{tabular}

出典: アルストム社資料（会社・シェア）と独自調査（本拠地）

この 2 ケ国では、この 30 年ほどの間に、新規にネット ワークが導入された都市が多く、「新設事業型」型の展 開の可能性の余地が大きかったといえる。特にフランス では 16 もの都市でトラムが「復活」しており、トラム における「新設事業型」展開の機会がきわめて多かった といえる。同様にイギリスでもある程度の機会があった といえる。これに対してドイツでは、20 世紀初頭まで にできたネットワークを拡張ないしは改良しながら現在 でも使っており、「新設事業型」の展開が行われる余地 は少なかったと言える。

トラム以外で「新設事業型」の可能性を持つもの、す なわち独自のインフラを持つ公共交通のモードの代表例 は鉄道である注7。しかし、ヨーロッパでは、高速鉄道 のような国家的プロジェクトのものや、Trans European Network といった欧州連合によるヨーロッパ全体のスケ 一ルの大規模な投資などを除けば、鉄道ネットワークを 新たに建設する、という事業は希である。こうした状況 を勘案すると、鉄道において「新設事業型」の機会が卜 ラムのようにあったとは考えにくい。

イギリスとフランスではトラムの「復活」の流れの中 で、「新設事業型」の形態での展開をはかる機会が多か ったが、ドイツではその機会が限られていたといえる。

\section{（4）本拠地の国の市場の開放の状況}

ここまでの観点とは別に、MOLTS が本拠とする国の 市場の状況を検討寸ると、フランスのみが特異な状況に あることがうかがえる。

イギリスの公共交通は、広く知られている通り、サッ チャー政権以降、民間ベースでの運営を原則としており、 市場は非常に開放的であると言える。これは鉄道、バス の両方について当てはまるといえる。ドイツは、伝統的 に地場の企業を重視した公共交通施策を行ってきたが、

EU の市場開放とともに、開放的な施策へと緩やかな転 換を推し進めてきたと言えよう。その結果、これまで鉄 道輸送を独占してきたドイツ鉄道 DB がある程度の危機 


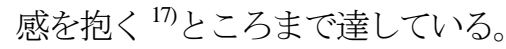

これらに対してフランスは、現在でも公共交通市場は かなりの程度において保護的である。鉄道は国鉄 SNCF が実質的に独占しており ${ }^{39}$ 、先述の Railway Liberalization Index も最下層に位置するなど、市場の開放はきわめて 限定的である。公共交通も市場シェアの 79\%を Veolia

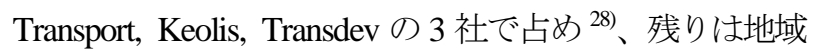
毎の企業などのため、事実上かなり保護的な市場である。

これらの状況と MOLTS の受け入れの状況はよく対応 している。イギリスやドイツでは多くの MOLTS を受け 入れており、イギリスはMOLTS を輩出もしているが、 フランスはMOLTS を輩出し、さらに先述のように「新 設事業型」を得意としているにもかかわらず、自国内に は他国本拠の MOLTS を受け入れてはいない。

\section{(5) フランスの MOLTS の強み}

以上をまとめると、イギリス、フランス、ドイツの これまでの状況を表 9 のように整理できる。MOLTS を 持つ英仏では、車両製造産業の有無と、国内市場の開放 の 2 点が異なる。フランスの MOLTS は、本拠とする自 国内にも「新設事業型」の機会を多数安定して持ち、か つ内外問わず「自国製品+MOLTS のオペレーション」 としての展開が可能であることから、「新設事業型」展 開での強みを持つことが読み取れる。また、ドイツには、 MOLTS そのものがなく、「新設事業型」展開の可能性 もほぼ皆無であるから、自然な帰結といえるだろう注 ${ }^{8)}$ 。

\section{6. まとめ}

本研究では、MOLTS の展開方法の差異や出自・経営 を分析することで、その特徵や背景を整理することを目 的として、はじめに(1)MOLTS の事業の展開が、トラム は「新設事業型」、鉄道は「既存事業置換型」、バスは 「他社吸収型」と、モードとの対応で整理できることを 示した上で、「新設事業型」はフランスの MOLTS のみ が得意とするとの知見を得た。さらに、(2)出資者や取締 役から、フランスの MOLTS が本拠地とする国の政府や 産業界と強いかがりを持っているとの示唆を得た。そ して、(3)車両の採択に着目すると、トラムの分野ではフ ランスの MOLTS は自国に製造拠点を持つメーカーのも のを重点的に採用し、さらに基本的な規格も実質的に標 準化されていることを明らかにした。さらに(4)英仏独の

表 9 MOLTS 形成・展開の背景の英仏独比較の総合

\begin{tabular}{|l|c|c|c|}
\hline \multicolumn{1}{|c|}{ 比較することがら } & 英 & 仏 & 独 \\
\hline MOLTS の存在 & $\bigcirc$ & $\bigcirc$ & $\times$ \\
\hline 強力な鉄道車両製造産業の有無 & $\times$ & $\bigcirc$ & $\bigcirc$ \\
\hline とラむでの「新設事業」の機会 & $\triangle$ & $\bigcirc$ & $\times$ \\
\hline 国内の公共交通市場の開放 & $\bigcirc$ & $\times$ & $\bigcirc$ \\
\hline ○:あり、 $\triangle:$ 多少あり、メ:なし & \multicolumn{3}{|c|}{ 出典 : 筆者作成 } \\
\hline
\end{tabular}

置かれた状況を整理することによって、フランスの MOLTS の「新設事業型」展開の強みについての知見を 得た。

では、これらから示唆されることは何であろうか。

わが国では「高密度・定時・安全」に代表される都 市鉄道のように、公共交通事業の実績は相当に蓄積して いると言える。特に、民間の経営マインドでの都市鉄道 事業は、かなり豊富な経験と実績を持っているといえる。 国内での都市鉄道での今後の輸送需要の大幅な伸びは期 待できない中で、国外に活路を見出す可能性を検討する 時期に来ているといえるであろう。企業としての成長可 能性の一つとして MOLTS のような展開をすることが十 分検討に值することは、アジア諸国の都市鉄道関心を持 つ MOLTS もある 44)ことからも示される。また、鉄道 車両産業のような関連の産業の蓄積もわが国には多い。

一方、MOLTS への特に出資者としての政府の影響力 や、おが国でも評価の高いフランスのトラム復活への MOLTS への関与を考えると、良質な公共交通の整備に は政府・公共セクターの強力な後押しが必要であること も改めて示唆される。特に MOLTS の事業は地方部にも 及んでおり、最初に述べたように「自治体相手・低リス ク・低収益」の事業であることを鑑みると、公共交通へ の公共セクターの関与の重要性が改めて示唆される。

今後の研究上は、第 1 章で示した(a)の MOLTS への 直接のヒアリングによる動機の調査や、第 4 章の最後に 述べた、MOLTS の展開と、トラム「復活」の流れが、 どのように影響しあっていたのかについての研究を進め たいと考えている。

\section{脚注}

注1) フランスのストラスブールのように、いったん廃止された都市のト ラムが「復活」した場合は、現時点で運行されているネットワークのみ を考慮し、いったん廃止されたネットワークは考慮していない。これ は、筆者らの既往の研究から、MOLTS の国際展開は 1990 年代以降であ り、その本格的な形成も 1980 年頃からであるが、トラムの「廃止」は 1970 年頃までが多く、時代的に重複していないことによる。

注 2) 英国の統計上は「Light Rail systems」としてロンドンの Docklands Light Railway と、ニューカッスルの Tyne and Wear Metro も一括りに扱わ れているが、これらは高架ないし地下を走る鉄道であるから、これら以 外の路面区間のある5つを「トラム」として扱った。

注3) Caisse des Dépôts はフランスの郵便貯金や貯蓄銀行の預金などと年 金基金の運用を手がける政府系金融蟣関である。また SNCF（フランス 国鉄）および RATP（パリ交通公団）はフランス国有の公共企業体であ る。さらにEDF はもともとフランス政府国有の電力会社であり、現在は 株式の一部が公開されているものの、8 割以上はフランス政府が保有さ れている。フランス政府自体は MOLTS の株主とはなっていないが、フ ランスのMOLTS はフランス政府の「血統」を持っているといえる。 注 4) 未開業であるが、Veolia Transport の事業地エルサレム (イスラエ ル）にアルストム社車両製が、Transdev の事業地エディンバラ (イギリ ス）にはスペインの CAF製の車両が導入される予定である。いずれも、 軌間 $1,435 \mathrm{~mm}$ 、直流 $750 \mathrm{~V}$ の規格である。

注5) ポルトは各所「メトロ」と表記されているが、道路上の専用軌道上 区間が市街にあることと、AdTranz/Bombardier の Eurotram を採用してい ることから、トラムに含めた。一方ジェノヴァは道路上の区間がなく車 両も地下鉄仕様のため、同じ「メトロ」でも除外した。

注 6) 同社資料によれば、北米での TGV の販売で提携している。 注 7)この他の「新設事業型」が可能なものの代表例としては、BRT が 挙げられる。アジアなどへの展開において、今後このモードでの展開が 増加すると予想される。 
注 8) ドイツは、現時点ではMOLTS を持たず、また「新設事業型」の可 能性も有してこなかったが、近年の EU の共通運輸政策 40043)などによる 変化は、MOLTS がドイツにも生まれる可能性を示している。すでに 16.3\%（列車キロ）の地域旅客輸送はドイツ鉄道以外が担っており ${ }^{17}$ 、 Metronom 社のようにドイツ国内で広くオペレーションを行う企業も現れ ている ${ }^{16}$ 。また、近年になってドイツ鉄道 DB も英国の鉄道一合弁で参 入を開始している ${ }^{26}$ 。したがって、ドイツ企業による MOLTS としての 展開も、ある種「時間の問題」だとも考えられる。

\section{主要参考文献}

1) 柴山多佳児、家田仁：「ローカルな公共交通サービスに事業展開寸る 「グローバル・オペレータ」」, 第36回土木計画学研究発表会, 2007 2) 柴山多佳児、家田仁：「ローカル公共交通サービスの「グローバル ・

オペレータ」」，「運輸と経済」2008年 10 月号

3) Veolia Transport : 2003 年、2004 年決算報告書、2007 年次報告書

4) Keolis : 2006 年、2007 年決算報告書

5) Arriva : 2006 年、2007 年決算報告書

6) Transdev : 2006 年、2007 年決算報告書

7) Veolia Environnement : 2007 年 年次報告書

8) Stagecoach Group (2007), Annual Report and Financial Statements 2007, Perth, Scotland

9) National Express Group PLC (2008) Making travel simpler... Annual Report and Accounts 2007, London

10) ComfortDelGro (2008), Annual Report 2007, Singapore

11) First Group (2008), 2008 Annual Report and Accounts

12) IBM Global Business Services (2007) Rail Liberalization Index 2007 - Market opening: comparison of the rail markets of the Member States of the European Union, Switzerland and Norway, IBM Corporation, Brussels

13) Department for Transport, the government of the United Kingdom “Light Rail Statistics - England: Key Facts" http://www.dft.gov.uk/

14) Groneck, Christoph (2003) "Neue Straßenbahnen in Frankreich" - die Wiederkehr eines urbanen Verkehrsmittels, EK-Verlag , Freiburg im Breisgau, Germany

15) VDV, Verband Deutscher Verkehrsunternehmen ; Bundesministerium für Verkehr-, Bau- und Wohnungswesen (2000), ,Stadtbahnen in Deutschland“, Alba Fachverl, Düsseldorf, Germany

16) Burmeister, J (2008) National und Global Players auf dem deutschen Nahverkehrsmarkt, Stadtverkehr, Vol. 53, No. 12, 38-41

17) Deutsche Bahn (2008) Competition Report 2008, Deutsche Bahn AG

18) Veolia Transport (2008a) Veolia Transport pursues expansion in Asia with signature of first contract in China, http://www. veoliatransport. com/en/company/press/20081208, nanjing. aspx

19）フォーブス社 : http://www. forbes. com/

20) フィナンシャル・タイムス誌 : http://www.ft. com/
21）ビジネス・ウィーク誌 : http://investing. businesweek. com/

22) Railway-Technology. com : http://www. railway-technology. com/

23) Schwandl, R., UrbanRail. Net, http://www. urbanrail. net/

24）望月真一（2001）『路面電車が街をつくる—21 世紀フランスの都市 づくり』鹿島出版会

25) Pucher J. and Kurth S. (1996), Verkehrsverbund: the success of regional public transport in Germany, Austria and Switzerland, Transport Policy Vol. 2. No. 4

26）小出直哉（2008），「欧州連合の運輸政策のゆくえ」，「運輸と経 済」 2008 年 10 月号

27）野田由美子編（2004）『民営化の戦略と手法』日本経済新聞社

28) Union des Transportes Publics et Ferroviaires (2008), Marche francais, http://www. utp. fr/index. php?option=com

content\&view_article\&id=15\&Itemid=15 [January 2009]

29) Stadtwerke München (c. a. 2006) SWM im Profil, http://www. swm. de/de/unternehmen/swm-profi1. html [Jan 2009]

30）カトリン・ケスタ、青木真美（2000）『ドイツにおける鉄道の地域化 (運輸と経済ブックレット No. 2)』運輸調查局

31）土方まりこ（2005）『ドイツにおける地域交通助成制度とその変 容』「運輸と経済」2005 年 11 月号 pp82-91

32）青木真美（2006）『ドイツにおける公共交通政策の最近の動向』 「運輸と経済」2006 年 11 月号 pp45-51

33) Alstom Transport (2006) "ALSTOM Transport Worldwide"

34）ボンバルディア社 : http://www. bombardier. com/

35) Macdonald. L (2002), “The Bombardier Story” , John Wiley \& Sons Canada Limited, Etobicoke, Ontario, Canada

36) ALSTOM Transport (2006) Tramway Solutions, Paris

37) ALSTOM Transport (2004) Kundenwünsche stets im Blick, Alstom Transport, Paris and Alstom LHB, Salzgitter, Germany

38) Siemens AG (c. a. 2007) Combino Plus - The new generation of 100-percent 1ow-floor trams from Siemens, Erlangen, Germany 39）廣崎 宗二（2000）『フランスの地方分権化と鉄道（運輸と経済ブッ クレット No. 1)』運輸調查局

40）橋本昌史（1994）『EC の運輸政策』日通総合研究所

41) IBM Business Consulting Services (2006), "Rail Regulation in Europe" , Zurich

42) European Commission (2001), White Paper - European transport policy for 2010: time to decide, Office for Official Publications of the European Communities, Luxembourg

43) European Commission (2006), Keep Europe moving - Sustainable mobility for our continent - Mid-term review of the European Commission's 2001 transport White Paper, Office for Official Publications of the European Communities, Luxembourg

44) Veolia Transpor (2009) Veolia Transport and RATP Développement set up joint venture to boost growth potential in Asiafrom http://www.veoliatransport.com/en/medias/press-releases/ratp-asia.htm

\section{ローカルな公共交通のオペレーションにおける多国籍事業の背景*}

本研究は、複数の国で独立した公共交通システムを運営するオペレータを MOLTS (Multinational Operators for Local Transport Services）と呼び、はじめにその展開の形態をモードとの対応で「新設事業型」、「既存事業置 換型」「他社吸収型」の 3 形態に整理た。また、フランスの MOLTS は「新設事業型」の展開において顕著 であるとの知見を得上で、これらは何らかの政府・産業界との経営上の強力な関係を形成し、特にトラムの 車両採用に顕れていることを明らかにした。さらに、英仏独の鉄道車両製造業の現状や「トラム復活」か ら、フランスには政府・産業界とのコンプレックスを形成して「新設事業型」の展開がしやすかった状況が あったことを明らかにした。

\section{Background of Multinational Businesses for Local Public Transport Operations *}

By Takeru Shibayama** and Hitoshi Ieda ***

This paper dealt with MOLTS (Multinational Operators for Local Transport Services), which operates independent local public transport systems in a number of cities in the world. Three different ways of evolution -'Development”, "Replacement”, “Absorption” - are found.. French MOLTS are especially active on "Development” evolution. Furthermore, French MOLTS forms implicit “Industrial Complex” with the country's industry as well as the government. Adoption of French-made tram rolling stock also highlights this; de-facto standardization is ongoing with French system. This research also discussed through comparison of Britain, France and Germany, that France provided more opportunities for "Development” evolution and forming “Industrial Complex” with its rolling stock manufacturing, tramway regeneration and so on. 